\title{
Studi Perbandingan Respon Struktur Rangka Baja Pemikul Momen terhadap Beban Gempa dan Beban Angin
}

\author{
AMATULHAY PRIBADI, ERMA DESMALIANA, \\ MOHAMMAD KENNETH RAFNI PRAYOGA
}

\author{
Program Studi Teknik Sipil, Institut Teknologi Nasional Bandung, Indonesia \\ Email: amatulhay.p@itenas.ac.id
}

\begin{abstract}
ABSTRAK
Perancangan struktur gedung yang baik diperlukan agar struktur dapat kuat dalam menahan beban gempa. Beban angin juga sebaiknya diperhitungkan sebagai beban lateral pada struktur gedung yang tinggi. Tujuan penelitian ini untuk mengetahui respon struktur gedung terhadap beban gempa dan beban angin yang terjadi pada tujuh wilayah di Indonesia berdasarkan SNI 1727:2020 dan SNI 1726:2019. Struktur gedung baja 10 lantai menggunakan sistem rangka pemikul momen khusus. Dari hasil penelitian, desain gedung telah aman terhadap simpangan antar tingkat yang disyaratkan. Pada penelitian ini, gaya geser dasar dari yang terbesar sampai yang terkecil menurut perhitungan gaya geser statik ekivalen dan respon spektra berturut-turut adalah Gorontalo, Jayapura, Banda Aceh, Kupang, Surabaya, Samarinda, dan Tanjung Pinang. Berdasarkan hasil analisis ini, beban gempa lebih berisiko mengakibatkan kegagalan struktur dibandingkan dengan beban angin.
\end{abstract}

Kata kunci: struktur rangka baja, beban gempa, beban angin

\begin{abstract}
A good structure design is necessary to ensure that the structure can resist the earthquake load. Wind load is also important to be accounted as lateral loads especially on tall buildings. This study aims to determine the building structural responses due to eathquake and wind loads which occur in seven regions in Indonesia based on SNI 1727:2020 and SNI1726:2019. The steel building structure is a 10-floor special moment resisting frame. Based on this research result, the design of the building is safe for displacement as required by the code. In this study, the base shear forces from the largest to the smallest consecutively based on equivalent static and response spectrum analysis are Gorontalo, Jayapura, Banda Aceh, Kupang, Surabaya, Samarinda, and Tanjung Pinang. Based on this research result, earthquake load has higher risk of causing structural failure than wind load.
\end{abstract}

Keywords: steel frame structure, earthquake load, wind load 


\section{PENDAHULUAN}

Indonesia merupakan negara yang sangat rentan terhadap gempa bumi dikarenakan letaknya yang berada di antara 3 (tiga) lempeng tektonik sehingga diperlukan perancangan dan pelaksanaan sistem struktur gedung tahan gempa yang memenuhi kaidah-kaidah yang disyaratkan (Zulkifli, E., 2017). Selain beban gempa, beban angin juga perlu diperhitungkan terutama pada struktur gedung tinggi. Tiap daerah memiliki besaran koefisien gempa dan kecepatan angin dasar yang berbeda-beda sehingga perilaku struktur gedung pada tiap wilayah pun berbeda juga. Oleh karena itu, perencana harus mempertimbangkan beban akibat gempa dan angin dengan baik bergantung pada lokasi dibangunnya struktur gedung.

Penelitian terkait yang telah dilakukan sebelumnya oleh Soelarso, Baehaki, dan Akhmad Mursyidan (2017) dengan menganalisis struktur gedung pada lima wilayah di Indonesia terhadap beban gempa dan beban angin berdasarkan SNI 1726-2012 dan SNI 1727-2013. Selain itu terdapat pula penelitian serupa dengan menggunakan studi kasus Gedung Menara Rektorat Kampus UNTIRTA Sindangsari oleh Baehaki, Zulmahdi Darwis, Hendrian Budi Bagus Kuncoro, dan Prastyani (2019). Oleh karena itu, pada penelitian ini akan dikaji respon dari struktur gedung baja terhadap beban lateral baik beban gempa maupun beban angin pada 7 (tujuh) wilayah di Indonesia berdasarkan SNI 1727:2020 dan SNI 1726:2019.

\section{TINJAUAN TEORITIS}

\subsection{Gedung}

Menurut KBBI gedung merupakan bangunan yang terbuat dari tembok dan sebagainya, berdimensi besar serta biasanya berfungsi sebagai tempat beraktivitas antara lain kantor, perjumpaan, perdagangan, pementasan, olahraga, dan sebagainya.

\subsection{Pembebanan}

Menurut SNI 1727:2020 beban merupakan gaya atau aksi lainnya yang diterima akibat berat seluruh material gedung, penghuni, barang yang terdapat dalam gedung, pengaruh lingkungan, selisih perpindahan, dan gaya kekangan akibat modifikasi dimensi.

\subsubsection{Beban Akibat Gaya Gravitasi}

Beban akibat gaya gravitasi mencakup beban mati dan beban hidup. Beban mati merupakan beban yang posisinya tetap. Beban ini disebut demikian dikarenakan beban tersebut bekerja terus-menerus di saat struktur sudah berfungsi. Tahapan perancangan beban tersebut berdasarkan Salmon, C. G., \& Johnson, J. E. (1996) yaitu estimasi awal berat, perhitungan ulang setelah desain selesai, dan revisi apabila diperlukan. Sedangkan beban hidup merupakan beban yang beraksi saat struktur gedung sudah beroperasi, yang besarnya bergantung pada besaran dan lokasi dari beban tersebut.

\subsubsection{Beban Akibat Gaya Luar}

Beban akibat gaya luar di antaranya beban yang diakibatkan oleh gempa bumi dan angin. Gempa bumi merupakan fenomena getaran di lapisan bumi, yang penyebab utamanya yaitu dampak pergeseran lapisan bumi sehingga menyebabkan gedung bergetar. Getaran tersebut menyebabkan massa gedung untuk mempertahankan dirinya dan menimbulkan gaya-gaya pada struktur gedung (Schodek, D. L., 1991). 


\subsubsection{Kombinasi Pembebanan}

Menurut SNI 1727:2020 struktur gedung sebaiknya didesain sedemikian rupa sehingga kekuatan desainnya sama atau melebihi pengaruh dari beban-beban terfaktor yang sudah ditentukan.

\subsection{Struktur Baja}

Struktur baja mencakup sub-struktur atau bagian dalam struktur gedung yang terbuat dari material baja struktural. Berdasarkan William, T. S. (2013), baja struktural merupakan material konstruksi yang dibentuk dengan komposisi kimia tertentu seperti karbon, fosfor, dan sulfur sebagai unsur tambahannya. Sebagai bahan konstruksi, baja memiliki kelebihan dan kekurangan, kelebihannya yaitu bersifat lebih lentur dan lebih ringan dibandingkan struktur lainnya, sedangkan kekurangannya yaitu rentan terjadi tekuk dan rentan terjadi korosi. Menurut Dewobroto, W. (2016), material baja memiliki keunggulan dari beton dan kayu dari segi parameter kekuatan, kekakuan, dan daktilitas.

\subsection{Perancangan Struktur Gedung Tahan Gempa}

Menurut SNI 1726:2019 perancangan struktur gedung baja tahan gempa dipengaruhi oleh beberapa parameter berikut.

\subsubsection{Desain Respon Spektra}

Menurut SNI 1726:2019 desain respon spektra dipengaruhi oleh kategori risiko dan faktor keutamaan seismik, kelas situs, parameter percepatan seismik $\left(S_{S}\right.$ dan $\left.S_{1}\right)$ dari peta seismik yang nantinya dimasukkan ke program ETABS.

\subsubsection{Gaya Lateral Ekivalen}

Gaya seismik lateral $\left(F_{x}\right)$ pada sembarang tingkat dihitung dengan Persamaan 1.

$$
F_{x}=C_{v x} V
$$

keterangan:

$$
\begin{array}{ll}
C_{v x} & =\text { faktor distribusi vertikal, } \\
V & =\text { gaya geser di dasar struktur [kN]. }
\end{array}
$$

\subsubsection{Simpangan Antar Tingkat}

Menurut SNI 1726:2019 simpangan antar tingkat desain $(\Delta)$ dapat dinyatakan sebagai perbedaan defleksi pada pusat massa di tingkat teratas dan terbawah yang dikaji. Defleksi pusat massa di tingkat $x\left(\delta_{x}\right)[\mathrm{mm}]$ dihitung dengan Persamaan 2.

$$
\delta_{x}=\frac{C_{d} \delta_{x e}}{I_{e}}
$$

keterangan:

$C_{d} \quad=$ faktor amplifikasi defleksi,

$\delta_{x e}=$ defleksi pusat massa di tingkat $x$,

$I_{e} \quad=$ faktor keutamaan seismik.

Simpangan antar tingkat desain tidak boleh melebihi simpangan antar tingkat izin yang ditentukan pada Tabel 1.

\subsection{Perancangan Beban Angin}

Menurut SNI 1727:2020, persayaratan umum kriteria penenuan beban angin pada SPGAU sebagai berikut: 
1. Beban angin desain yang dipengaruhi oleh kecepatan angin dasar $(V)$ dalam perancangan struktur gedung.

2. Kategori eksposur yang dipengaruhi oleh kekasaran permukaan tanah berdasarkan topografi alam, vegetasi, dan fasilitas dibangun.

3. Faktor arah angin $\left(K_{d}\right)$ yang dipengaruhi oleh tipe struktur gedung yang akan dibangun.

4. Efek topografi $\left(K_{Z T}\right)$ yang dipengaruhi oleh perbedaan tinggi topografi.

5. Efek tiupan angin halmana jika suatu gedung yang dibangun adalah kaku, maka boleh diambil sebesar 0,85.

6. Faktor elevasi permukaan tanah $\left(K_{e}\right)$ yang dipengaruhi oleh elevasi tanah di atas permukaan laut.

Tabel 1. Simpangan Antar Tingkat Izin

\begin{tabular}{llcc}
\hline \multicolumn{1}{c}{ Struktur } & \multicolumn{3}{c}{ Kategori Risiko } \\
\cline { 2 - 4 } & I atau II & II & IV \\
\hline $\begin{array}{l}\text { Struktur selain dari struktur } \\
\text { dinding geser batu bata, } 4 \\
\text { tingkat atau kurang dengan } \\
\text { dinding interior, partisi, } \\
\text { langit-langit dan sistem } \\
\text { dinding eksterior yang telah } \\
\text { didesain } \\
\text { mengakomodasi simpangan } \\
\text { antar lantai tingkat }\end{array}$ & $0,025 h_{s x}$ & $0,020 h_{s x}$ & $0,015 h_{s x}$ \\
\hline $\begin{array}{l}\text { Struktur dinding geser } \\
\text { kantilever batu bata }\end{array}$ & $0,010 h_{s x}$ & $0,010 h_{s x}$ & $0,010 h_{s x}$ \\
\hline $\begin{array}{l}\text { Struktur dinding geser batu } \\
\text { bata lainnya }\end{array}$ & $0,007 h_{s x}$ & $0,007 h_{s x}$ & $0,007 h_{s x}$ \\
\hline Semua struktur lainnya & $0,020 h_{s x}$ & $0,015 h_{s x}$ & $0,010 h_{s x}$ \\
\hline
\end{tabular}

(Sumber: SNI 1726:2019)

keterangan:

$h_{s x}=$ tinggi tingkat di bawah tingkat $x$.

\section{METODE PENELITIAN}

\subsection{Prosedur Penelitian}

Adapun prosedur yang dikerjakan dalam penelitian ini, diawali oleh studi literatur dari penelitian-penelitian terdahulu dan preliminary design untuk penentuan awal balok, kolom, dan pelat untuk gedung. Setelah dilakukan preliminary design, dapat dibuat 7 pemodelan gedung pada wilayah yang diteliti, dan apabila belum memenuhi persyaratan SNI 1726:2019, SNI 1727:2020, dan SNI 1729:2020, maka balok dan kolom ditentukan dengan cara autoselect pada software ETABS. Setelah pemodelan selesai dan sudah memenuhi kriteria, hasil analisis struktur dari software ETABS dapat dibandingkan gaya geser dasar dan simpangan antar tingkatnya untuk menentukan wilayah yang paling berisiko baik terhadap beban gempa maupun beban angin. Setelah seluruh analisis dan perbandingan dikerjakan, lalu kesimpulan pun didapatkan dari penelitian ini beserta saran untuk menyempurnakan penelitian ini.

\subsection{Studi Pustaka}

Pada tahapan ini dilakukan pengkajian teori-teori dasar yang berhubungan dengan perancangan struktur gedung baja, yang kuat menahan beban gempa dan beban angin. Sumber dari studi pustaka ini adalah buku, literatur, jurnal, artikel, dan penelitian sebelumnya. 


\subsection{Penentuan Variabel Desain}

Pada penelitian ini, apartemen akan dirancang dengan denah gedung tertera pada Gambar 2, sedangkan lokasi penelitian tertera pada Gambar 3.

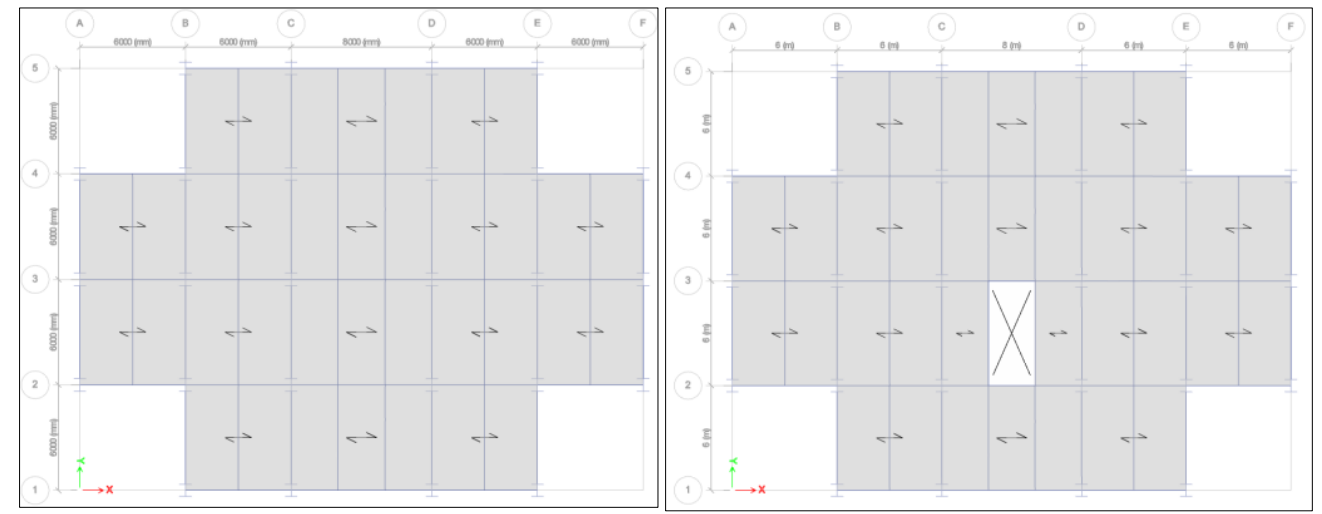

Gambar 2. Denah gedung tipikal lantai 1-9 dan lantai atap

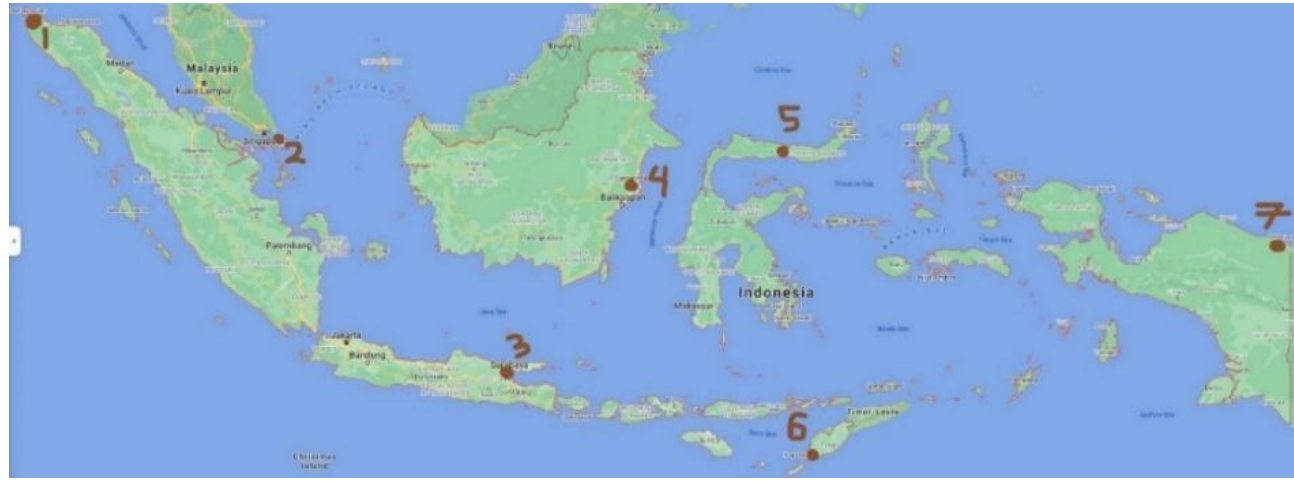

Gambar 3. Lokasi tinjauan

\subsection{Beban Gempa dan Beban Angin Rencana}

Beban gempa rencana, dihitung menggunakan analisis respon spektra. Titik daerah yang diamati adalah Aceh, Kepulauan Riau, Surabaya, Kupang, Samarinda, Gorontalo, dan Jayapura. Daerah tersebut diambil berdasarkan lokasinya yang letaknya berbeda-beda pulau satu dengan yang lainnya, agar dapat dianalisis perbedaan perilaku struktur di tiap-tiap daerah tersebut. Pada perancangan struktur gedung baja ini, beban angin dipengaruhi oleh kecepatan angin dasar yang bersumber dari BMKG, yang datanya diambil dari BPS. Beban angin dihitung berdasarkan SNI 1727:2020.

\subsection{Pemodelan dan Pengecekan Kapasitas Struktur Gedung}

Setelah mendapat seluruh data yang dibutuhkan dan melakukan preliminary design, permodelan gedung menggunakan perangkat lunak ETABS dapat dilakukan. Perangkat lunak ETABS digunakan karena dapat memudahkan pengerjaan penelitian ini. Permodelan yang dilakukan meliputi material data profil baja, dimensi kolom, dimensi balok, serta pembebanan. Pada perangkat lunak ETABS dapat diperoleh nilai gaya yang bekerja pada gedung yaitu gaya aksial dan geser komponen balok dan kolom dalam menahan gaya-gaya yang bekerja.

\subsection{Perbandingan Analisis Struktur}

Setelah dimodelkan dan kapasitas gedung dalam menahan gaya-gaya sudah memumpuni, lalu dilakukan perbandingan respon struktur pada 7 wilayah yang dianalisis. Analisis struktur dapat dilakukan apabila pemodelan pada perangkat lunak ETABS telah selesai dan dapat dijalankan. Analisis struktur yang dibandingkan pada penelitian ini, ialah gaya geser dasar dan simpangan (displacement). 


\section{HASIL PENELITIAN DAN PEMBAHASAN}

\subsection{Data Struktur}

Data struktur yang digunakan pada penelitian ini mencakup data umum, material, dan dimensi baja profil, seperti tertera pada Tabel $\mathbf{2}$ dan Tabel $\mathbf{3}$.

Tabel 2. Data Struktur

\begin{tabular}{ll}
\hline & Data Umum Struktur \\
\hline Jumlah Lantai & $: 10$ lantai (termasuk atap) \\
\hline Luas Bangunan & $: 624 \mathrm{~m}^{2}$ \\
\hline Tinggi Lantai & $: 31 \mathrm{~m}$ \\
\hline Fungsi Gedung & $:$ apartemen \\
\hline Mutu Beton & $: f_{c}^{\prime} 25 \mathrm{MPa}$ \\
\hline Mutu Baja & $: \mathrm{BJ} 41$ \\
\hline
\end{tabular}

Tabel 3. Data Balok-kolom

\begin{tabular}{|c|c|c|c|c|}
\hline Profil Baja & $\begin{array}{c}H \\
{[\mathrm{~mm}]}\end{array}$ & $\begin{array}{c}B \\
{[\mathrm{~mm}]}\end{array}$ & $\begin{array}{c}t_{w} \\
{[\mathbf{m m}]}\end{array}$ & $\begin{array}{c}t_{f} \\
{[\mathrm{~mm}]}\end{array}$ \\
\hline W 16x77 & 419,1 & 261,2 & 11,6 & 19,3 \\
\hline W 10x27 & 261,6 & 146,6 & 6,6 & 11,2 \\
\hline W 14×370 & 454,7 & 419,1 & 42,2 & 67,6 \\
\hline Built Up $600 \times 600$ & 600 & 600 & 70 & 85 \\
\hline Built Up $600 \times 600$ & 600 & 600 & 80 & 95 \\
\hline
\end{tabular}

\subsection{Beban Gempa}

Beban gempa yang digunakan didapat dari website puskim.pu.go.id. Semua wilayah tinjauan dianggap memiliki nilai $R=8$ dan nilai $C_{d}=5,5$. Beban gempa yang digunakan tertera pada Tabel 4

Tabel 4. Data Beban Gempa

\begin{tabular}{cccccccc}
\hline Variabel & Banda Aceh & Tanjung Pinang & Surabaya & Kupang & Samarinda & Gorontalo & Jayapura \\
\hline$S_{S}[\mathrm{~g}]$ & 1,307 & 0,052 & 0,673 & 1,13 & 0,125 & 1,594 & 1,5 \\
\hline$S_{1}[\mathrm{~g}]$ & 0,573 & 0,077 & 0,256 & 0,299 & 0,089 & 0,628 & 0,6 \\
\hline$F_{a}$ & 1 & 1,6 & 1,262 & 1,048 & 1,6 & 1 & 1 \\
\hline$F_{v}$ & 1,727 & 2,4 & 2,088 & 2,002 & 2,4 & 1,7 & 1,7 \\
\hline$S_{M S}[\mathrm{~g}]$ & 1,307 & 0,083 & 0,849 & 1,184 & 0,2 & 1,594 & 1,5 \\
\hline$S_{M 1}[\mathrm{~g}]$ & 0,990 & 0,185 & 0,535 & 0,599 & 0,214 & 1,068 & 1,02 \\
\hline$S_{D S}[\mathrm{~g}]$ & 0,87 & 0,06 & 0,57 & 0,79 & 0,13 & 1,06 & 1,00 \\
\hline$S_{D 1}[\mathrm{~g}]$ & 0,66 & 0,12 & 0,36 & 0,40 & 0,14 & 0,71 & 0,63 \\
\hline$T_{0}[\mathrm{detik}]$ & 0,151 & 0,444 & 0,126 & 0,101 & 0,214 & 0,134 & 0,126 \\
\hline$T_{S}[$ detik] & 0,757 & 2,220 & 0,630 & 0,506 & 1,068 & 0,670 & 0,630 \\
\hline
\end{tabular}

(Sumber: puskim.pu.go.id)

\subsection{Beban Angin}

Data beban angin yang digunakan yaitu kecepatan angin dasar (wind speed), diperoleh dari website Badan Pusat Statistik Indonesia yaitu bps.go.id. Dari data yang diperoleh, kemudian dirata-ratakan dengan hasil seperti tertera pada Tabel $\mathbf{5}$.

Tabel 5. Data Kecepatan Angin Dasar 


\begin{tabular}{ccccc}
\hline Provinsi & Kota & $\begin{array}{c}\text { Kecepatan Angin Dasar } \\
{[\mathbf{m} / \mathbf{s}]}\end{array}$ & $\begin{array}{c}\text { Kecepatan Angin Dasar } \\
{[\mathbf{k m} / \mathbf{j a m}]}\end{array}$ & $\begin{array}{c}\text { Kecepatan Angin Dasar } \\
{[\mathbf{m p h}]}\end{array}$ \\
\hline Aceh & Banda Aceh & 4,58 & 16,488 & 10,245 \\
\hline Kepulauan Riau & Tanjung Pinang & 6,13 & 22,068 & 13,712 \\
\hline Jawa Timur & Surabaya & 10,19 & 36,684 & 22,794 \\
\hline Nusa Tenggara Timur & Kupang & 4,78 & 17,208 & 10,693 \\
\hline Kalimantan Timur & Samarinda & 3,16 & 11,376 & 7,069 \\
\hline Gorontalo & Gorontalo & 1,54 & 5,544 & 3,444 \\
\hline Papua & Jayapura & 4,10 & 14,76 & 9,171 \\
\hline
\end{tabular}

(sumber: bps.go.id)

Kriteria yang diaplikasikan pada penelitian ini antara lain kategori kekasaran permukaan $\mathrm{B}$ dengan kategori eksposur B; faktor arah angin $\left(K_{d}\right)$ sebesar 0,85; faktor elevasi tanah sebesar 1 ; dan faktor elevasi tanah $\left(K_{Z T}\right)$ sebesar 1 .

\subsection{Hasil Analisis Struktur Gedung terhadap Beban Gempa dan Beban Angin}

Analisis struktur gedung baik terhadap beban gempa maupun beban angin berdasarkan analisis perhitungan statik ekivalen dan respon spektra, diperoleh nilai simpangan antar tingkat dan gaya geser dasar di tiap wilayah yang dikaji. Kemudian besaran gaya yang mempengaruhi struktur gedung dibandingkan antar tiap wilayah akibat beban gempa dan beban angin.

\subsubsection{Gaya Geser Dasar Statik Ekivalen dan Gaya Geser Dasar Respon Spektra} Berdasarkan grafik pada Gambar 4 dan Gambar 5, dapat disimpulkan bahwa gaya geser dasar terbesar baik akibat statik ekivalen maupun akibat respon spektra berturut-turut yaitu Gorontalo, Jayapura, Banda Aceh, Kupang, Surabaya, Samarinda, dan Tanjung Pinang. Besarnya gaya geser dasar dipengaruhi oleh nilai $S_{S}$ dan $S_{1}$. Semakin besar nilai $S_{S}$ dan $S_{1}$, maka semakin besar gaya geser dasar yang didapatkan struktur gedung.

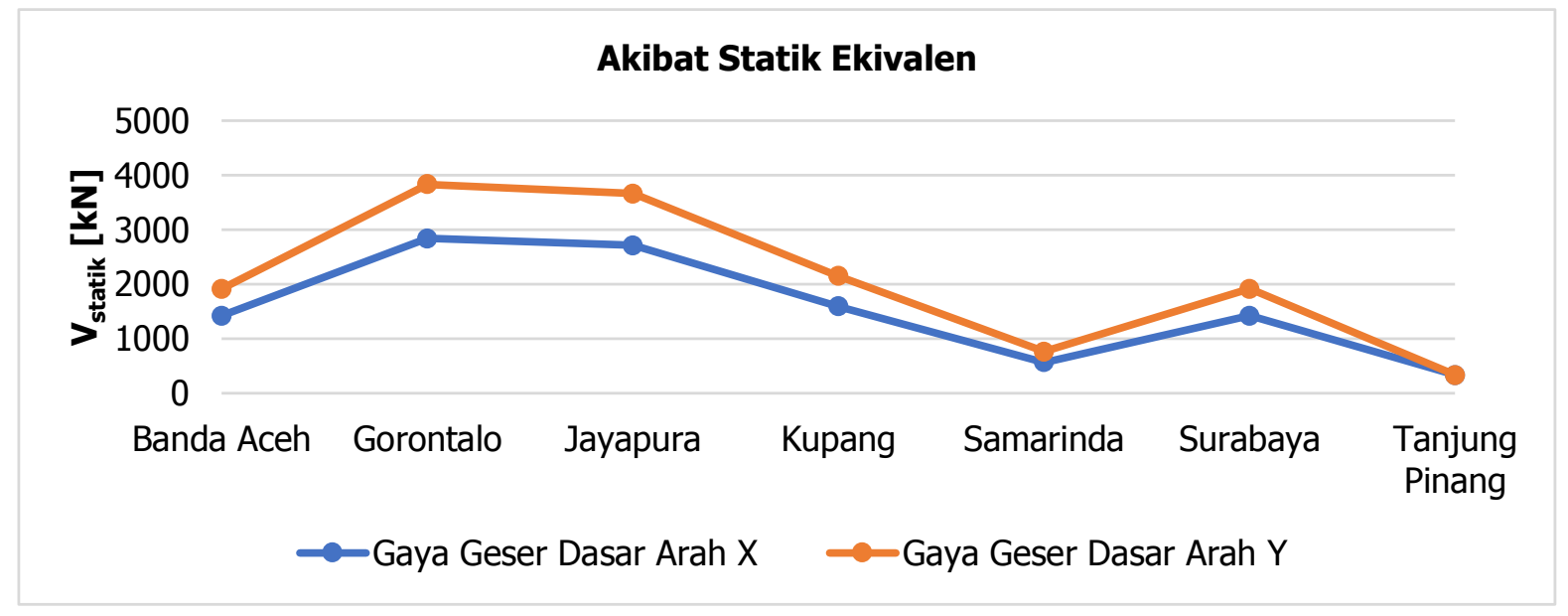

Gambar 4. Gaya geser dasar akibat statik ekivalen 


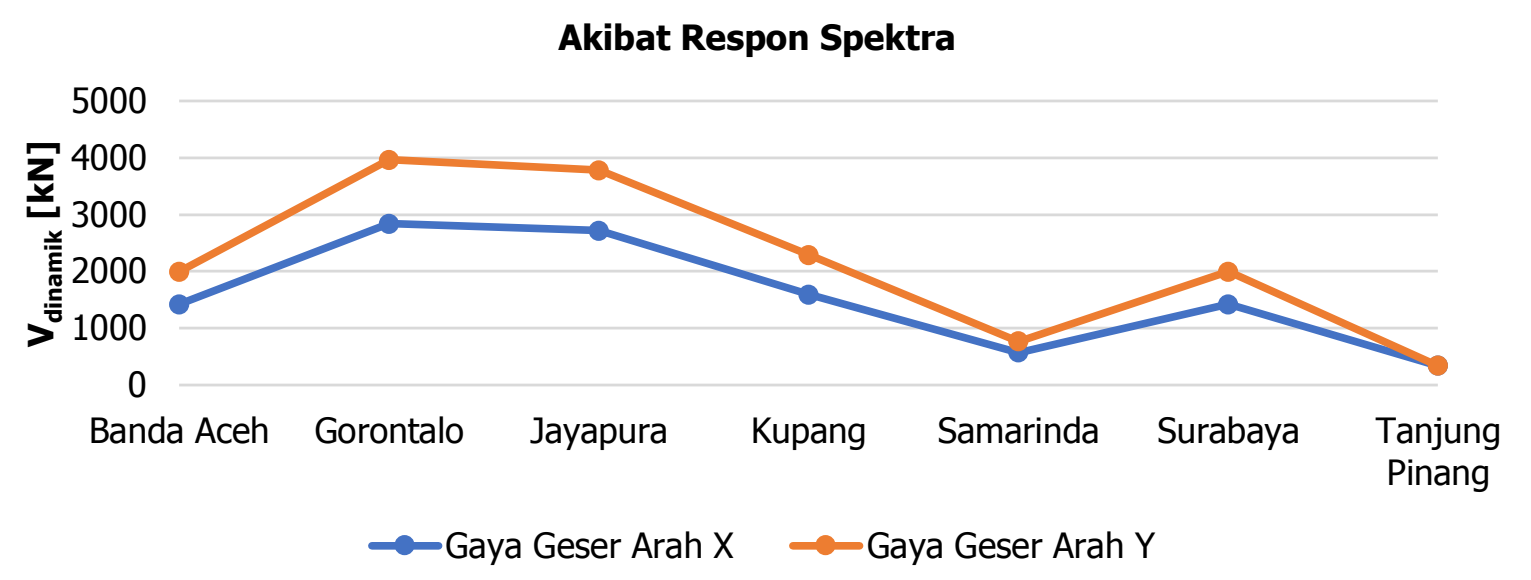

\section{Gambar 5. Gaya geser dasar akibat respon spektra}

\subsubsection{Simpangan Antar Tingkat}

Dari hasil analisis simpangan antar tingkat struktur gedung di semua wilayah, didapatkan bahwa semua pemodelan memenuhi simpangan yang disyaratkan pada SNI 1726:2019. Struktur gedung di wilayah Gorontalo memiliki simpangan antar tingkat arah $\mathrm{x}$ dan y paling besar dibandingkan wilayah yang lain, sedangkan Tanjung Pinang menjadi wilayah yang simpangan antar tingkatnya paling kecil, hal ini dipengaruhi oleh koefisien percepatan seismik. Simpangan antar tingkat pada masing-masing wilayah seperti tertera pada Gambar $\mathbf{6}$ dan Gambar 7.

\subsubsection{Perbandingan Perpindahan Antar Tingkat Antara Beban Gempa dan Beban Angin}

Perbandingan nilai perpindahan struktur gedung baik akibat beban gempa maupun beban angin tertera pada Gambar 8 dan Gambar 9.

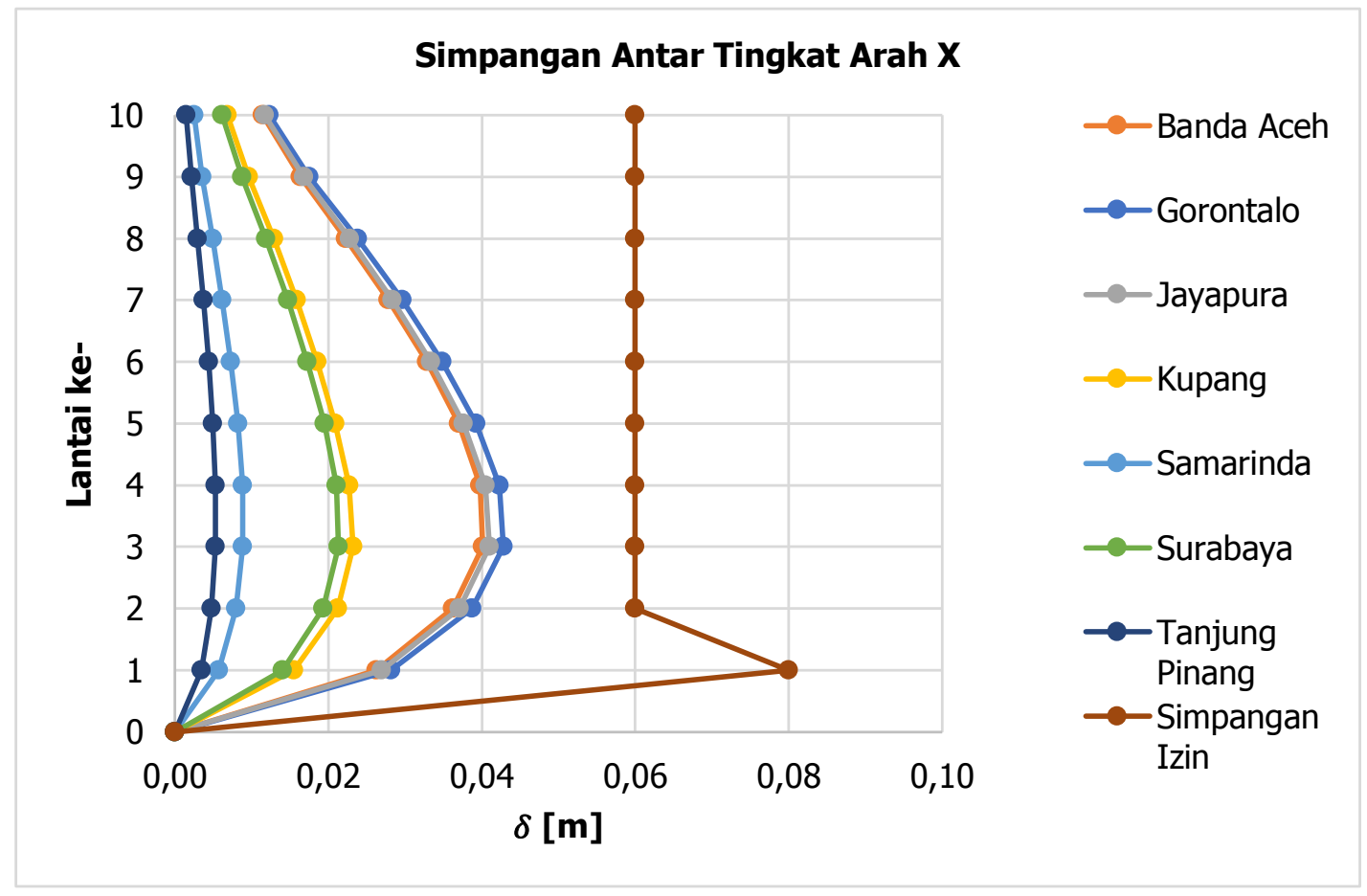


Gambar 6. Simpangan antar tingkat arah $X$ akibat beban gempa

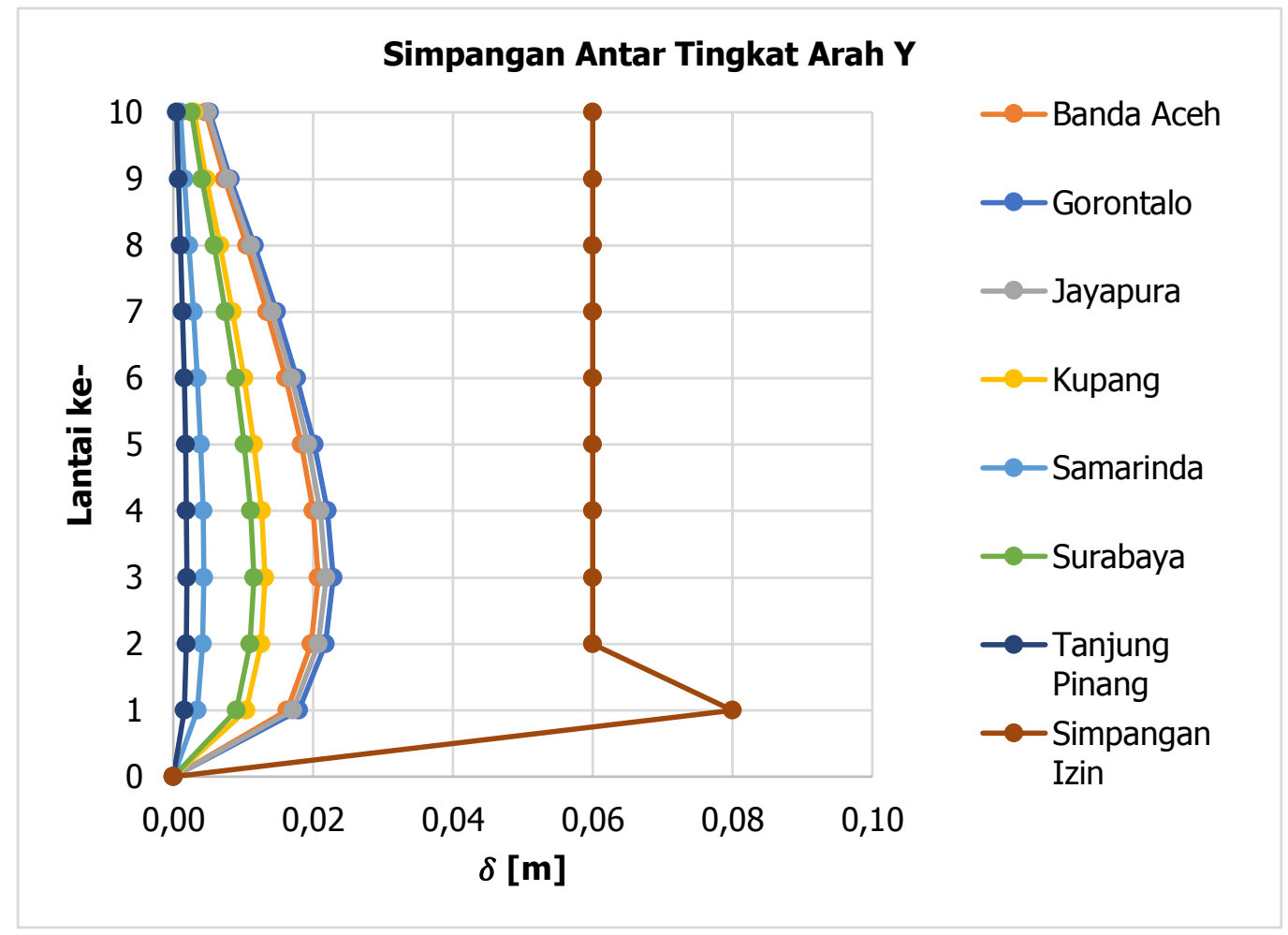

Gambar 7. Simpangan antar tingkat arah $Y$ akibat beban gempa

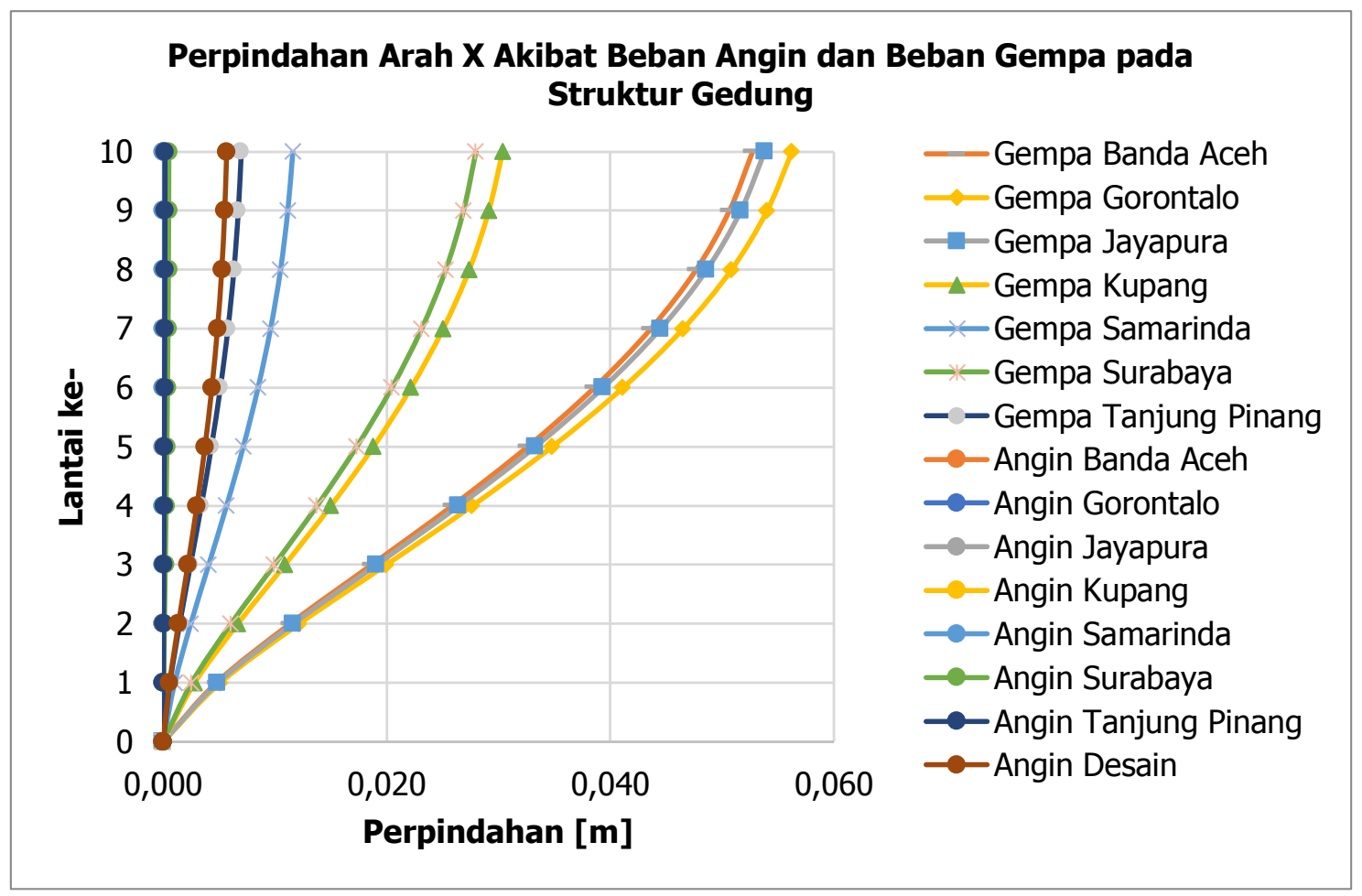

Gambar 8. Perpindahan arah $\mathrm{X}$ akibat beban gempa dan angin 


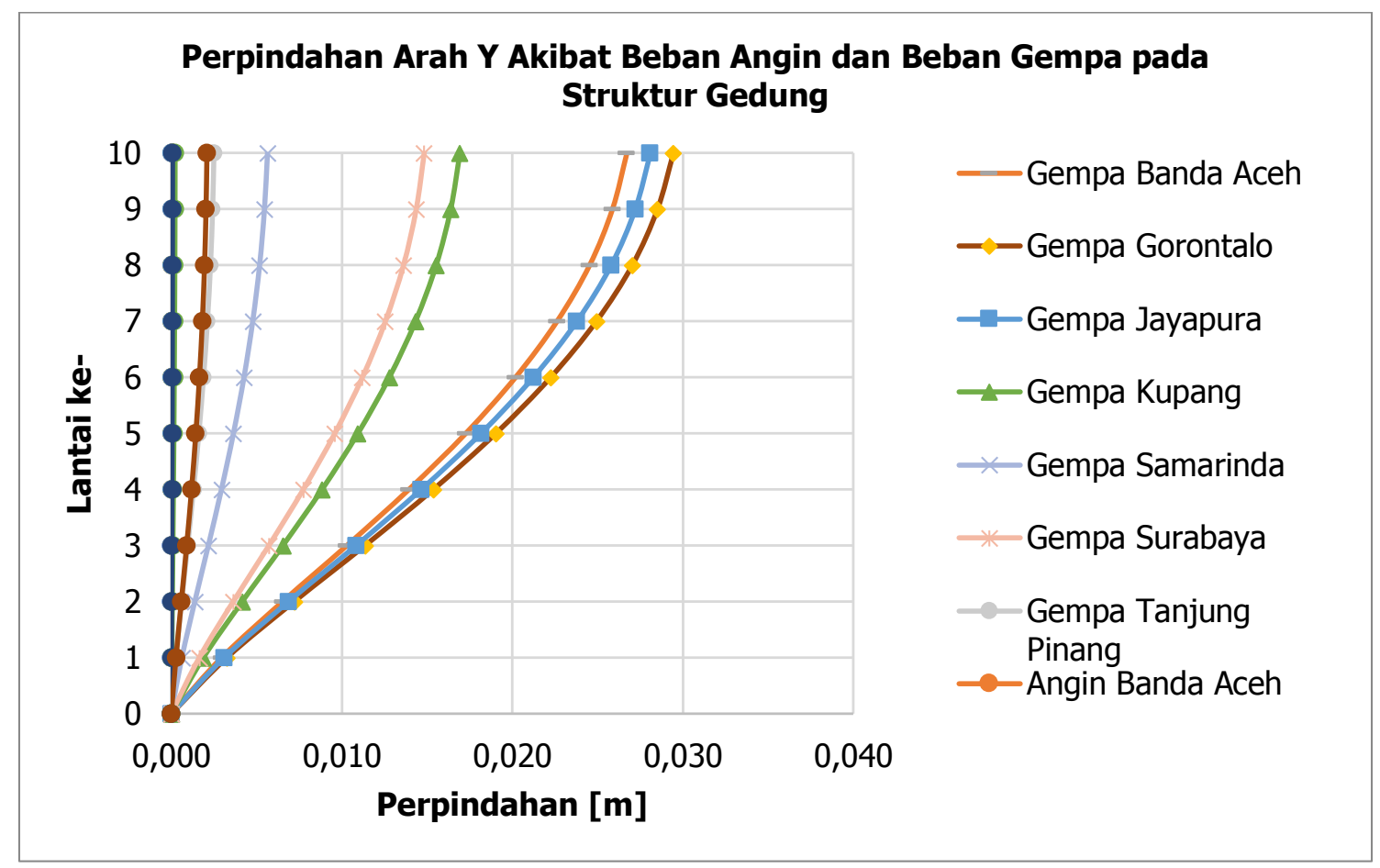

Gambar 9. Perpindahan arah $\mathrm{Y}$ akibat beban gempa dan angin

Dari seluruh analisis respon struktur gedung baik akibat beban gempa maupun beban angin, dapat disimpulkan bahwa beban gempa lebih berisiko menyebabkan kegagalan struktur dibandingkan dengan beban angin seperti tertera pada Gambar 8 dan Gambar 9. Beban angin paling dipengaruhi oleh kecepatan angin dasar, sedangkan beban gempa paling dipengaruhi oleh koefisien percepatan gempa.

\section{KESIMPULAN}

Kesimpulan yang didapatkan dari hasil penelitian adalah sebagai berikut:

1. Berdasarkan analisis struktur, kapasitas komponen struktur gedung yang digunakan telah memenuhi persyaratan dalam menahan baik beban gempa maupun beban angin pada struktur gedung, namun dimensi balok dan kolom belum cukup ekonomis.

2. Baik gaya geser tingkat maupun gaya geser dasar akibat beban gempa terbesar sampai terkecil berturut-turut yaitu Gorontalo, Jayapura, Banda Aceh, Kupang, Surabaya, Samarinda, dan Tanjung Pinang. Besarnya nilai $S_{S}$ dan $S_{1}$ pada parameter percepatan seismik mempengaruhi gaya geser dasar yang terjadi. Pada penelitian ini, wilayah paling aman terhadap beban gempa yaitu Tanjung Pinang, hal ini disebabkan oleh wilayahnya yang memiliki tingkat risiko kegempaan yang rendah (kategori desain seismik B), sedangkan wilayah yang paling berisiko terhadap beban gempa yaitu Gorontalo (kategori desain seismik D).

3. Berdasarkan hasil analisis, struktur gedung baja bertingkat 10 lantai yang dirancang telah memenuhi persyaratan simpangan antar tingkat izin yang ditetapkan oleh SNI 1726:2019 dan SNI 1727:2020.

4. Pada penelitian ini, wilayah yang paling aman terhadap beban angin yaitu Gorontalo, sedangkan wilayah yang paling rawan terhadap beban angin yaitu Surabaya. Beban angin yang diterima struktur gedung bergantung pada kecepatan angin dasar yang digunakan. Semakin besar kecepatan angin dasar, maka semakin besar pula gaya yang diterima struktur gedung akibat beban angin. 


\section{Studi Perbandingan Respon Struktur Rangka Baja Pemikul Momen terhadap Beban Gempa dan Beban Angin}

5. Analisis yang dilakukan terhadap respon struktur gedung menghasilkan bahwa beban gempa lebih berisiko mengakibatkan kegagalan struktur gedung dibandingkan dengan beban angin. Kesimpulan ini berlaku khusus pada tipe struktur gedung dan jumlah lantai yang digunakan pada penelitian ini.

\section{SARAN}

Adapun saran yang dibutuhkan untuk penelitian ini sebagai berikut:

1. Perlu dilakukan perbandingan dengan struktur gedung baja menggunakan perkuatan seperti bracing atau dinding geser.

2. Perlu dilakukan analisis kinerja struktur, untuk menentukan level kinerja struktur.

3. Perlu dilakukan perbandingan antara perpindahan akibat beban angin baik hasil dari perhitungan aplikasi ETABS maupun dari perhitungan manual.

4. Sebaiknya menggunakan data kecepatan angin pada ketinggian $10 \mathrm{~m}$ seperti yang telah ditentukan oleh SNI 1727:2020.

\section{DAFTAR PUSTAKA}

Baehaki, Zulmahdi Darwis, Hendrian Budi Bagus Kuncoro, Prastyani. (2019). Perbandingan Respons Struktur Akibat Beban Gempa dan Pengaruh Angin Pada Gedung Bertingkat Tinggi. Banten: Jurusan Teknik Sipil Fakultas Teknik Universitas Sultan Ageng Tirtayasa.

Dewobroto, W. (2016). Struktur Baja Edisi ke-2. Tangerang: Lumina Press.

Salmon, C. G., \& Johnson, J. E. (1996). Steel Structures: Design and Behavior (Fourth Edition). New York: HarperCollins College Pubishers.

Schodek, D. L. (1991). Struktur. Bandung: PT. Eresco.

SNI 1726:2019. (2019). Tata cara perencanaan ketahanan gempa untuk struktur bangunan gedung dan non gedung. DKI Jakarta: Badan Standarisasi Nasional.

SNI 1727:2020. (2020). Beban desain minimum dan kriteria terkait untuk bangunan gedung dan struktur lain. DKI Jakarta: Badan Standarisasi Nasional.

SNI 1729:2020. (2020). Spesifikasi untuk bangunan gedung baja struktural. DKI Jakarta: Badan Standarisasi Nasional.

Soelarso, Baehaki, Akhmad Mursyidan. (2017). Analisis Struktur Gedung Bertingkat di Lima Wilayah di Indonesia Terhadap Beban Gempa dan Beban Angin Berdasarkan SNI 1726-2012 dan SNI 1727-2013. Banten: Jurusan Teknik Sipil, Fakultas Teknik, Universitas Sultan Ageng Tirtayasa.

William, T. S. (2013). Steel Design Fifth Edition. Stamford: Global Engineering.

Zulkifli, E. (2017). Perencanaan Struktur Beton Bertulang. Bandung: FTSL ITB Prodi Teknik Sipil. 